RESEARCH PAPER

\title{
Carcinogen derived biomarkers: applications in studies of human exposure to secondhand tobacco smoke
}

\section{S S Hecht}

See end of article for authors' affiliations

....................

Correspondence to: Professor Stephen S Hecht, University of Minnesota Cancer Center, Mayo Mail Code 806, 420 Delaware Street SE, Minneapolis, MN 55455, USA; hecht002@umn.edu

Received

16 December 2002

Accepted 24 July 2003
Objective: To review the literature on carcinogen derived biomarkers of exposure to secondhand tobacco smoke (SHS). These biomarkers are specifically related to known carcinogens in tobacco smoke and include urinary metabolites, DNA adducts, and blood protein adducts.

Method: Published reviews and the current literature were searched for relevant articles.

Results: The most consistently elevated biomarker in people exposed to SHS was 4-(methylnitrosamino)-1(3-pyridyl)-1-butanol (NNAL) and its glucuronides (NNAL-Gluc), urinary metabolites of the tobacco specific lung carcinogen 4-(methylnitrosamino)-1-(3-pyridyl)-1-butanone (NNK). The tobacco specificity of this biomarker as well as its clear relation to an established lung carcinogen are particularly appropriate for its application in studies of SHS exposure.

Conclusion: The results of the available carcinogen derived biomarker studies provide biochemical data which support the conclusion, based on epidemiologic investigations, that SHS causes lung cancer in nonsmokers.
$\mathrm{T}$ he International Agency for Research on Cancer (IARC) will soon publish a report on secondhand tobacco smoke (SHS). ${ }^{1}$ It concludes that SHS causes lung cancer in humans. This conclusion agrees with the evaluations of other groups which have previously examined this issue. ${ }^{2-6}$ It is based on over 50 epidemiologic studies of involuntary smoking and lung cancer risk in never smokers. These studies are bolstered by biochemical data demonstrating carcinogen uptake in non-smokers exposed to SHS. These biomarker studies are the subject of this review.

SHS, also known as environmental tobacco smoke, is produced mainly by the release of smoke from the burning tip of a cigarette between puffs (sidestream smoke, or SS) and the smoke exhaled by the smoker (exhaled mainstream smoke). Small additional contributions come from the tip of the cigarette and through the cigarette paper during a puff, and through the paper and mouth end of the cigarette between puffs. ${ }^{7}$ Similar considerations apply to other forms of tobacco smoking such as cigars and pipes.

Figure 1 presents a framework for considering mechanisms of lung cancer induction by SHS. An analogous scheme has been proposed as an outline of lung cancer induction in smokers. ${ }^{8}$ Carcinogens are responsible for the cancer causing effects of tobacco smoke. It is very likely that the broad mechanisms of cancer induction by SHS and mainstream cigarette smoke are similar because the same carcinogens are present in both, although in different relative concentrations. The major difference is that the carcinogen dose from SHS exposure is significantly less than that from smoking.

\section{CARCINOGENS IN SS AND SHS}

Constituents of cigarette mainstream smoke and SS have been discussed in a number of publications..$^{9}{ }^{10}$ Table 1 summarises representative levels of carcinogens in SS and SHS. ${ }^{10}$ Structures of the organic compounds are shown in fig 2. Table 1 includes only compounds that have been evaluated by IARC and for which there is sufficient evidence of carcinogenicity in either laboratory animals or humans. Many of these compounds have also been evaluated by the US National Toxicology Program. ${ }^{3}$ It also includes only compounds for which there are published data on levels in
SS or SHS. The amounts of each constituent are taken from representative publications. A number of other tobacco smoke carcinogens which have been evaluated by IARC are not included in table 1 because there are no published data on their levels in SS or SHS. It is likely, however, that these compounds are also present. In addition, there may be carcinogens present that have not been fully characterised or evaluated by IARC.

Polycyclic aromatic hydrocarbons (PAH) are a diverse group of carcinogens formed in the incomplete combustion of organic material. These carcinogens are found in tobacco smoke, broiled foods, and polluted environments of various types. Workers in iron and steel foundries and aluminium production plants are exposed to $\mathrm{PAH}$. These exposures are thought to be the cause of excess cancers in these settings. ${ }^{11} 12$ Benzo[a]pyrene ( $\mathrm{BaP})$ is the best known member of this class of compounds. PAH are potent locally acting carcinogens in laboratory animals. They induce tumours of the upper respiratory tract and lung when administered by inhalation, instillation in the trachea, or implantation in the lung. ${ }^{13}{ }^{14}$ When administered orally, BaP does not generally cause lung tumours in mice and rats, but rather causes tumours of the digestive tract. ${ }^{15-18}$

$\mathrm{N}$-Nitrosamines are a large group of carcinogens which induce cancer in a wide variety of species and tissues. There is no reason to assume that humans should be resistant to the effects of these carcinogens. ${ }^{19}$ They are present at low concentrations in foods and can be formed endogenously from amines and nitrogen oxides. ${ }^{20}$ Tobacco smoke contains volatile $\mathrm{N}$-nitrosamines such as $\mathrm{N}$-nitrosodimethylamine and $\mathrm{N}$ nitrosopyrrolidine as well as tobacco-specific $N$-nitrosamines

\footnotetext{
Abbreviations: 8-OH-dG, 8-hydroxydeoxyguanosine; BaP, benzo[a]pyrene; GC-MS, gas chromatography-mass spectrometry; HPB, 4-hydroxy-1-(3-pyridyl)-1-butanone; IARC, International Agency for Research on Cancer; NNAL, 4-(methylnitrosamino)-1-(3-pyridyl)-1butanol; NNK, 4-(methylnitrosamino)-1-(3-pyridyl)-1-butanone; NNN, $N^{\prime}$-nitrosonornicotine; PAH, polycyclic aromatic hydrocarbons; SHS, secondhand smoke; SS, sidestream smoke; HMA, trans, trans-muconic acid
} 


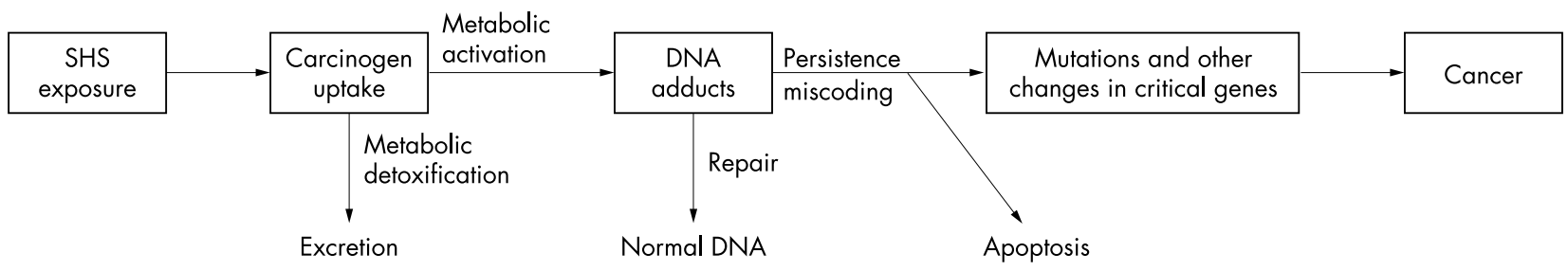

Figure 1 Scheme showing the steps which would link secondhand smoke (SHS) exposure and cancer via tobacco smoke carcinogens.

such as $N^{\prime}$-nitrosonornicotine and 4-(methylnitrosamino)-1(3-pyridyl)-1-butanone (NNK). ${ }^{21}$ Tobacco specific $N$-nitrosamines are chemically related to nicotine and other tobacco alkaloids and are therefore found only in tobacco products or related materials. ${ }^{22}$ Many $\mathrm{N}$-nitrosamines are powerful carcinogens in laboratory animals. They display striking organospecificity, affecting particular tissues, often independent of the route of administration. ${ }^{19}$ For example, $N^{\prime}$ nitrosonornicotine causes tumours of the oesophagus and nasal cavity in rats, while the principal target of NNK in

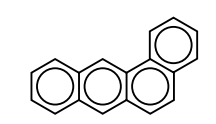

benzo[a]anthracene

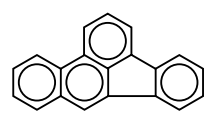

benzo[b]fluoranthene

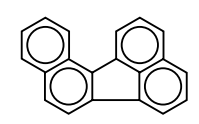

benzo[j]fluoranthene

Figure 2 Structures of the organic carcinogens in sidestream smoke and secondhand tobacco smoke (see table 1).

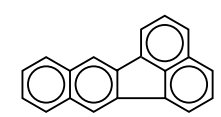

benz[k]fluoranthene

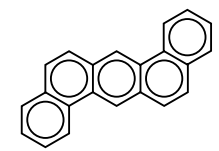

dibenz $[a, h]$ anthracene

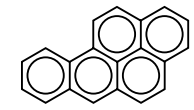

benzo[a]pyrene

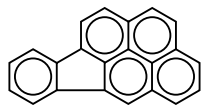

indeno[1,2,3-cd]pyrene<smiles>CN(C)N=O</smiles>

$\mathrm{N}$-nitrosodimethylamine<smiles>O=NN1CCCCC1</smiles>

$\mathrm{N}$-nitrosopiperidine<smiles>O=NN1CCCC1c1cccnc1</smiles>

$N$ '-nitrosonornicotine<smiles>Nc1ccc2ccccc2c1</smiles>

2-naphthylamine<smiles>CC(=O)CC(C)=O</smiles><smiles>C=CC(=C)C</smiles>

isoprene

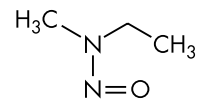

$\mathrm{N}$-nitrosoethylmethylamine<smiles>O=NN1CCCC1</smiles>

$\mathrm{N}$-nitrosopyrrolidine<smiles>CN(CCCC(=O)c1cccnc1)N=O</smiles>

4-(methylnitrosamino)-1(3-pyridyl)-1-butanone<smiles>Nc1ccc(-c2ccccc2)cc1</smiles>

4-aminobiphenyl<smiles>Cc1ccccc1O</smiles>

catechol<smiles>c1ccccc1</smiles>

benzene<smiles>CCN(CC)N=O</smiles>

$\mathrm{N}$-nitrosodiethylamine<smiles>O=NN(CCO)CCO</smiles>

$\mathrm{N}$-nitrosodiethanolamine<smiles>Cc1ccccc1N</smiles>

2-tolvidine<smiles>C=O</smiles>

formaldehyde<smiles>C=CC=C</smiles>

1,3-butadiene

$\mathrm{H}_{2} \mathrm{C} \rightleftharpoons \mathrm{C} \equiv \mathrm{N}$

acrylonitrile 
Table 1 Carcinogens in sidestream smoke (SS) and secondhand smoke (SHS) of cigarettes*

\begin{tabular}{|c|c|c|c|}
\hline \multirow[b]{2}{*}{ Carcinogens } & \multicolumn{2}{|c|}{ Representative amounts } & \multirow[b]{2}{*}{ References } \\
\hline & SS (per cigarette) & SHS $\left(\right.$ per $\mathrm{m}^{3}$ ) & \\
\hline \multicolumn{4}{|c|}{ Polycyclic aromatic hydrocarbons (PAH) } \\
\hline benz[a]anthracene & $201 \mathrm{ng}$ & $0.32-1.7 \mathrm{ng}$ & 84,85 \\
\hline Benzo[b]fluoranthene & & & 84,85 \\
\hline Benzo[j]fluoranthene $\}$ & $196 \mathrm{ng}$ & $0.79-2.0 \mathrm{ng}$ & 84,85 \\
\hline Benzo[ $k]$ fluoranthene $\int$ & & & 84,85 \\
\hline Benzo[a]pyrene & $45-103 \mathrm{ng}$ & $0.37-1.7 \mathrm{ng}$ & $84-86$ \\
\hline Indeno[ $[1,2,3-c d]$ pyrene & $51 \mathrm{ng}$ & $0.35-1.1 \mathrm{ng}$ & 84,85 \\
\hline Dibenz $[a, h]$ anthracene & & $1 \mathrm{ng}$ & 87 \\
\hline \multicolumn{4}{|l|}{$\mathrm{N}$-nitrosamines } \\
\hline$N$-nitrosodimethylamine & $143-1040 \mathrm{ng}$ & $4-240 \mathrm{ng}$ & $88-90$ \\
\hline $\mathrm{N}$-nitrosoethylmethylamine & $3-35 \mathrm{ng}$ & & 88,90 \\
\hline $\mathrm{N}$-nitrosodiethylamine & $8.2-73 \mathrm{ng}$ & $20-200 \mathrm{ng}$ & 88,90 \\
\hline$N$-nitrosopiperidine & $4.8-19.8 \mathrm{ng}$ & & 86 \\
\hline $\mathrm{N}$-nitrosopyrrolidine & $7-700 \mathrm{ng}$ & $3.5-27.0 \mathrm{ng}$ & $88-91$ \\
\hline $\mathrm{N}$-nitrosodiethanolamine & $43 \mathrm{ng}$ & & 92 \\
\hline$N^{\prime}$-nitrosonornicotine (NNN) & $110-857 \mathrm{ng}$ & $0.7-23 \mathrm{ng}$ & $86,89,93,94$ \\
\hline $\begin{array}{l}\text { 4-(methylnitrosamino)-1-(3- } \\
\text { pyridyl)-1-butanone (NNK) }\end{array}$ & $201-1440 \mathrm{ng}$ & $0.2-29.3 \mathrm{ng}$ & $86,89,93,94$ \\
\hline \multicolumn{4}{|l|}{ Aromatic amines } \\
\hline 2-tolvidine & $3030 \mathrm{ng}$ & & 95 \\
\hline 2-naphthylamine & $63.1-128 \mathrm{ng}$ & & 96 \\
\hline 4-aminobiphenyl & $11.4-18.8 \mathrm{ng}$ & & 96 \\
\hline \multicolumn{4}{|l|}{ Aldehydes } \\
\hline Formaldehyde & $233-485 \mu \mathrm{g}$ & $143 \mu \mathrm{g}$ & 96,97 \\
\hline Acetaldehyde & $961-1820 \mu \mathrm{g}$ & $268 \mu \mathrm{g}$ & 96,97 \\
\hline \multicolumn{4}{|l|}{ Miscellaneous organics } \\
\hline Catechol & $98-292 \mu \mathrm{g}$ & $1.24 \mu \mathrm{g}$ & $96-98$ \\
\hline 1,3-butadiene & $98-205 \mu \mathrm{g}$ & $0.3-40 \mu \mathrm{g}$ & $96,97,99,100$ \\
\hline Isoprene & $668-1260 \mu \mathrm{g}$ & $657 \mu \mathrm{g}$ & 96,97 \\
\hline Benzene & $163-353 \mu \mathrm{g}$ & $4.2-63.7 \mu \mathrm{g}$ & $68,96,97,99,100$ \\
\hline Acrylonitrile & $42-109 \mu \mathrm{g}$ & & 96 \\
\hline \multicolumn{4}{|l|}{ Inorganic compounds } \\
\hline Hydrazine & $94 \mathrm{ng}$ & & 101 \\
\hline Nickel & $51 \mathrm{ng}$ & & 96 \\
\hline Chromium & $57-79 \mathrm{ng}$ & & 96 \\
\hline Cadmium & $330-689 \mathrm{ng}$ & $4-38 \mathrm{ng}$ & 96,102 \\
\hline Lead & $28.9-46.6 \mathrm{ng}$ & & 96 \\
\hline Polonium-210 & $0.091-0.139 \mathrm{pCi}$ & & 103 \\
\hline
\end{tabular}

rodents is the lung. NNK is the only tobacco smoke carcinogen that induces lung tumours systemically in all three commonly used rodent models-rat, mouse, and hamster. ${ }^{23}$

Aromatic amines were first identified as carcinogens as a result of industrial exposures that occurred in the dye industry. Among these, 2-naphthylamine and 4-aminobiphenyl are well established human bladder carcinogens. ${ }^{24} 25$ Aromatic amines cause tumours at a variety of sites in laboratory animals. Some members of this class such as 2 -toluidine are only weakly carcinogenic. ${ }^{26}$

Formaldehyde and acetaldehyde induce respiratory tract tumours in rodents when administered by inhalation. ${ }^{27} 28$ They are weaker carcinogens than $\mathrm{PAH}, N$-nitrosamines, and aromatic amines, but their levels in SS and SHS are thousands of times higher. Butadiene and benzene are volatile hydrocarbons which also occur in considerable quantities in SS and SHS. Butadiene is a multi-organ carcinogen, with particular potency in mice, while benzene causes leukemia in humans..$^{29-31}$ Metals such as nickel and cadmium are human carcinogens which are also present in $\mathrm{SS}^{32}{ }^{33}$

There are also reports that SS contains free radicals in about the same concentration as mainstream smoke. ${ }^{34}$ The gas phase is reported to have reactive yet long lived radicals while the particulate phase apparently has a free radical system which is an equilibrium mixture of semiquinones, hydroquinones, and quinones. ${ }^{35}$ It is not known whether such agents can induce tumours in laboratory animals.

\section{CARCINOGEN DERIVED BIOMARKERS: APPLICATIONS IN SHS STUDIES}

Figure 1 shows that carcinogens undergo metabolism which may lead either to detoxification and excretion or to activation to a more reactive form that can bind to DNA. Most carcinogens in SHS require metabolism for binding to DNA, although some will react directly. Covalent binding to DNA results in production of "DNA adducts" in which the carcinogen metabolite is chemically bound to one of the DNA bases or to phosphate. This binding is critical to the carcinogenic process. There are cellular repair mechanisms which can remove these adducts and return the DNA to its normal form, but these are not always efficient. If the adducts persist during DNA replication, miscoding can occur leading to permanent mutations. Apoptosis, or programmed cell death, removes some mutated cells. If the mutations occur in critical genes such as oncogenes and tumour suppressor genes, loss of normal cellular growth control processes can result and, ultimately, cancer occurs. The constant barrage of DNA damaging carcinogens experienced upon exposure to SHS is completely consistent with the multiple genetic changes known to occur in lung cancer and other cancers. These genetic changes are known to be associated with six proposed "hallmarks of cancer": self sufficiency in growth signals; evasion of apoptosis; insensitivity to anti-growth signals; sustained angiogenesis; tissue invasion and metastasis; and limitless replicative potential. ${ }^{36}$

Carcinogen derived biomarkers, which are analytes directly related to specific carcinogens, are produced during the 


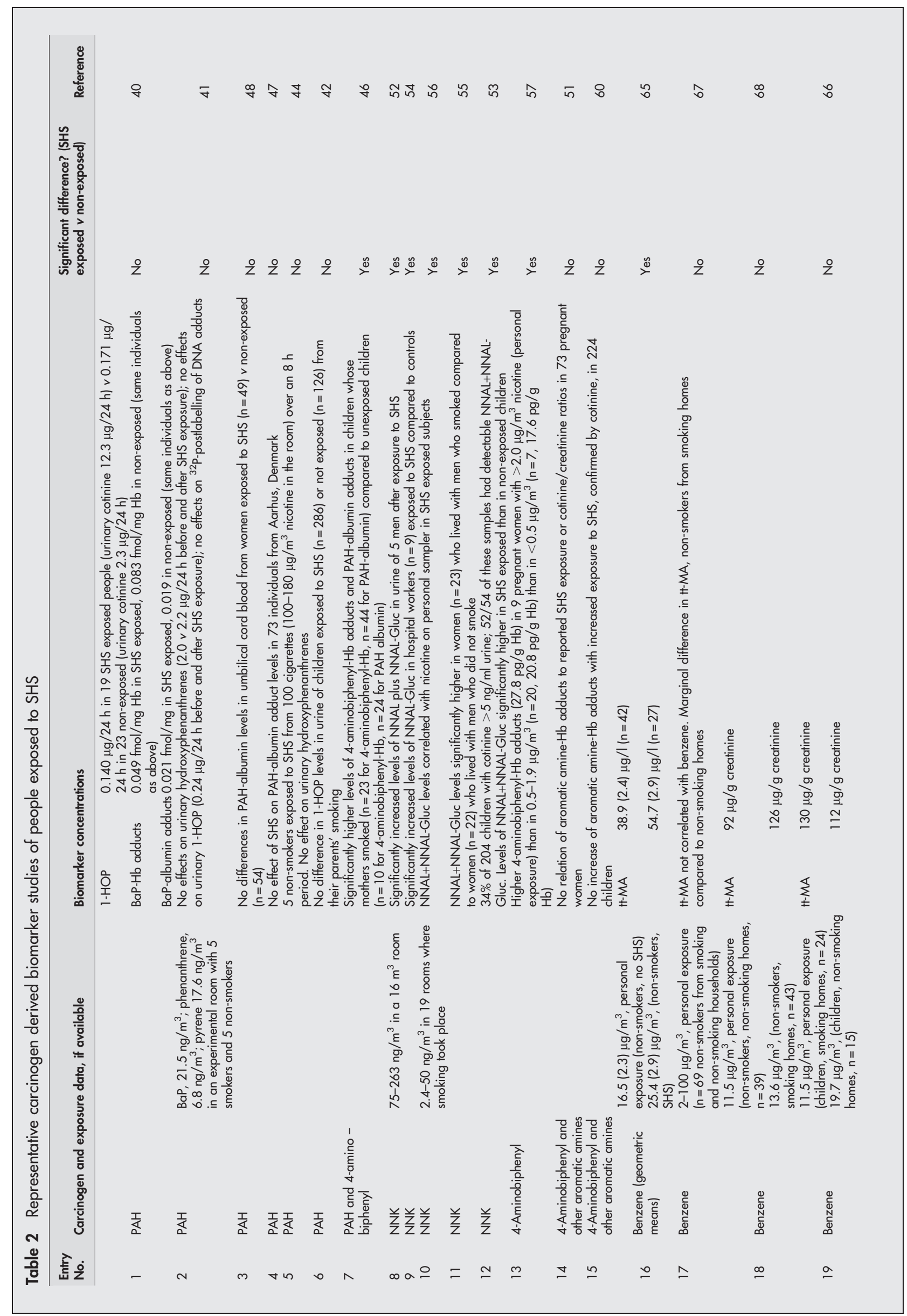




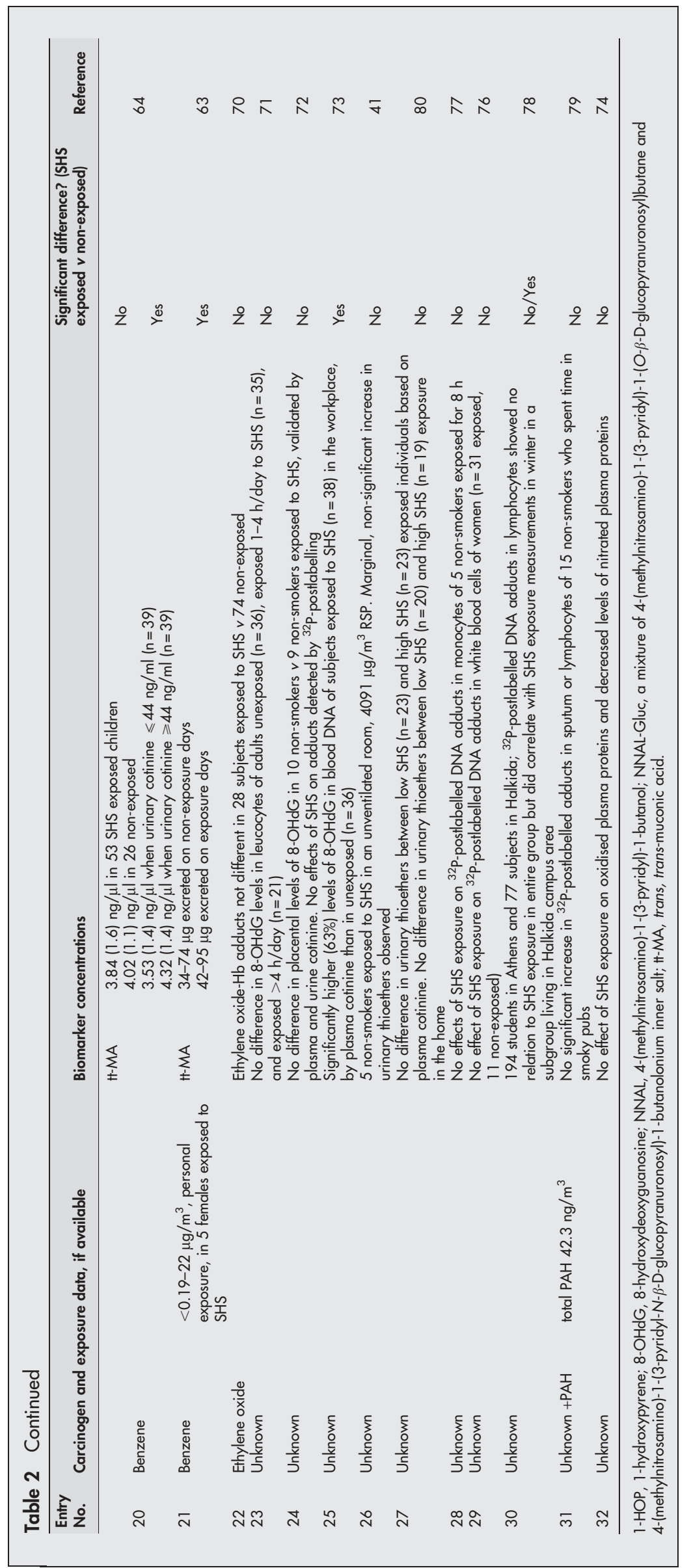




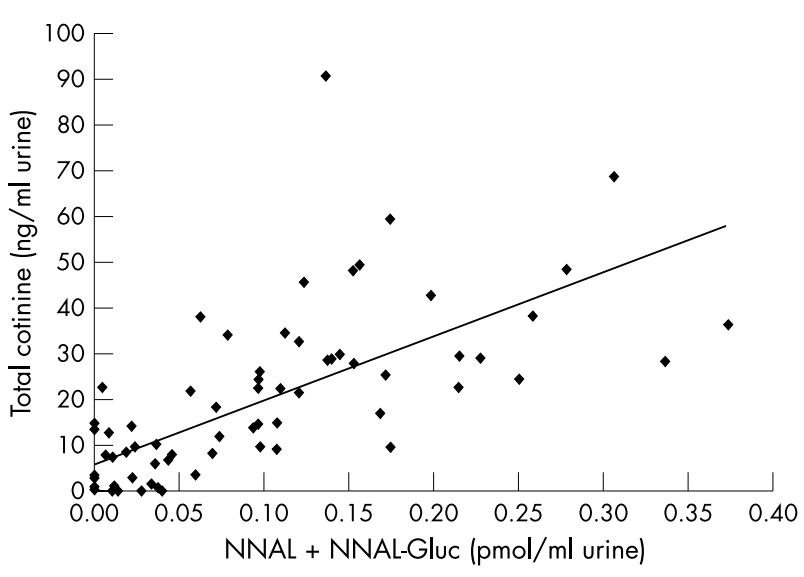

Figure 3 Correlation between levels of cotinine plus cotinineglucuronide and NNAL plus NNAL-Gluc in the urine of 74 school aged children exposed to SHS $(r=0.69$, $p<0.0001) .^{53}$

events outlined in fig 1 . These biomarkers have the potential to provide information on cancer risk. ${ }^{37}$ Three main types of carcinogen derived biomarkers have been measured in humans exposed to SHS: carcinogens and their metabolites in urine; DNA adducts in white blood cells and sputum; and adducts to haemoglobin or albumin in blood. Carcinogens and their metabolites in urine provide information about carcinogen dose. DNA adduct measurements give an indication of dose to DNA, the critical target in carcinogenesis. Haemoglobin and albumin adducts are not directly involved in the carcinogenic process, but they are often used as surrogates for DNA adducts, because they are more readily measured and in many cases their levels correlate with those of DNA adducts. This review will discuss carcinogen derived biomarkers as applied to studies of SHS exposure. Studies on cotinine, a major metabolite of the non-carcinogen nicotine widely used in investigations of SHS exposure, will not be discussed here except as they relate to carcinogen derived biomarkers. $^{38}$

Table 2 summarises data on human uptake of specific carcinogens from SHS, as determined by measurement of carcinogen derived biomarkers. These studies provide a link between SHS exposure and uptake of actual carcinogens to which people are exposed. This topic has been reviewed previously. ${ }^{39}$

Several methods have been used to estimate PAH uptake in humans exposed to SHS. 1-Hydroxypyrene and hydroxyphenanthrenes are urinary metabolites of pyrene and phenanthrene, respectively. These metabolites are widely used as biomarkers of PAH uptake although the parent compounds, pyrene and phenanthrene, are non-carcinogenic. Levels of l-hydroxypyrene and hydroxyphenanthrenes in urine are not increased by exposure to SHS. ${ }^{40-44}$ Other factors such as smoking, occupational exposures, and diet are significant contributors to the levels of these compounds in urine.
Metabolites of $\mathrm{BaP}$ and other $\mathrm{PAH}$ form adducts with haemoglobin and serum albumin. These adducts have been measured by a variety of methods, including immunoassay and gas chromatography-mass spectrometry (GC-MS). Using a relatively non-specific immunoassay technique, one group has found increased levels of PAH-albumin adducts in SHS exposed children, ${ }^{45}{ }^{46}$ but an increment in levels of this marker with SHS exposure was not found in two other studies. ${ }^{47} 48$ An effect of SHS exposure on albumin and haemoglobin adducts of $\mathrm{BaP}$ was not found in a recent study which used GC-MS as the detection method. ${ }^{40}$ Thus, the evidence that SHS exposure significantly increases human uptake of PAH is inconsistent.

Since tobacco specific $N$-nitrosamines are found only in tobacco products or related nicotine containing materials, their adducts or metabolites should be specific biomarkers of tobacco exposure. Haemoglobin adducts of NNK and NNN can be hydrolyzed to release 4-hydroxy-1-(3-pyridyl)-1butanone (HPB), which is quantified by GC-MS. In smokers, levels of HPB releasing haemoglobin adducts of NNK and NNN are low compared to haemoglobin adducts of several other carcinogens, possibly because of the high reactivity of the alkylating intermediate. ${ }^{49}{ }^{50}$ Considering the relatively low levels of these adducts in smokers, one would not expect to find significantly elevated amounts in non-smokers exposed to SHS, as reported by Branner et al. ${ }^{51}$ Metabolites of NNK are readily measured in the urine of people exposed to SHS. The metabolites 4-(methylnitrosamino)-1-(3-pyridyl)-1-butanol (NNAL) and its glucuronide conjugates NNAL-Gluc- are quantified by GC with nitrosamine-selective detection (GCTEA). ${ }^{52-56}$ All studies reported to date show significantly higher amounts of NNAL plus NNAL-Gluc, or NNAL-Gluc, in the urine of SHS exposed humans than in unexposed controls (table 2). In one study, uptake of NNK was over six times higher in women who lived with smokers compared to women who lived with non-smokers.5 ${ }^{55}$ In another investigation, widespread uptake of NNK was demonstrated in a group of economically disadvantaged schoolchildren, and the range of levels varied over 90 -fold. ${ }^{53}$ Most studies to date demonstrate a correlation between levels of cotinine and NNAL plus NNAL-Gluc in urine (fig 3). Cotinine is a reliable biomarker for nicotine uptake by non-smokers exposed to SHS, and has been widely used in studies of SHS exposure. ${ }^{38}$ NNAL plus NNAL-Gluc is a biomarker for uptake of the tobacco specific lung carcinogen NNK by non-smokers exposed to SHS. The NNAL plus NNAL-Gluc biomarker is more directly related to cancer risk than cotinine because NNK but not nicotine is carcinogenic. The uptake of NNK, a potent lung carcinogen, by non-smokers exposed to SHS provides a biochemical link between SHS exposure and lung cancer.

Aromatic amines such as 4-aminobiphenyl form adducts with haemoglobin that can be quantified by GC-MS. Mixed results have been obtained in studies of the effects of SHS on 4-aminobiphenyl haemoglobin adduct levels. Hammond et al demonstrated that adduct levels were elevated in pregnant

Table 3 Relation of carcinogen derived biomarkers to SHS exposure*

\begin{tabular}{llll}
\hline Carcinogen in SHS & Biomarker & Association with SHS exposure & References \\
\hline PAH & $\begin{array}{l}\text { 1-Hydroxypyrene in urine } \\
\text { Hydroxyphenanthrenes in urine }\end{array}$ & None in most studies & $40-43,45-48$ \\
& $\begin{array}{l}\text { PAH-albumin adducts } \\
\text { PAH-haemoglobin adducts }\end{array}$ & & \\
NNK & NNAL and NNAL-Gluc in urine & Consistently increased & $52-56$ \\
$\begin{array}{l}\text { Aromatic amines } \\
\text { Benzene }\end{array}$ & Haemoglobin adducts & Mixed results & $46,51,57-60$ \\
& trans, trans-Muconic acid in urine & Mixed results & $63-68$
\end{tabular}

${ }^{*}$ Modified from Scherer and Richter. ${ }^{39}$ 
women exposed to SHS. ${ }^{57}$ Maclure et al observed slightly higher levels of haemoglobin adducts of 4-aminobiphenyl and 3-aminobiphenyl in persons with confirmed SHS exposure compared with unexposed persons. ${ }^{58}$ 4-Aminobiphenyl haemoglobin adducts were also elevated in children exposed to SHS. ${ }^{46}$ However, two other studies, including one of pregnant women, showed no consistent relation between adduct levels and SHS exposure. ${ }^{5159}$ A study in German children also showed no significant increase in aromatic amine haemoglobin adduct levels with increasing SHS exposure; in fact there was a significant decrease in ortho- and meta-toluidine adducts. ${ }^{60}$ There is a background level of aromatic amine haemoglobin adducts in apparently unexposed humans. The origin of this background is unknown, but it could be due in part to uptake of the corresponding nitro compounds from sources such as diesel emissions. Levels of aromatic amines in urine were unaffected by exposure to SHS. ${ }^{61}$

trans,trans-Muconic acid (tt-MA) is a urinary metabolite of benzene which has been widely used to estimate benzene uptake. ${ }^{62}$ Mixed results have been obtained in studies on the relation of this metabolite to SHS exposure, with some studies showing somewhat higher levels in people exposed to SHS while others found no effect. ${ }^{63-68}$ Interpretation of these findings is complicated by differing excretion rates among individuals and contributions of sources other than benzene, such as sorbate in food, to its levels in urine. ${ }^{396367}$ Benzene itself has been quantified in exhaled breath. Breath measurements of non-smokers who reported exposure to smokers at work showed elevated benzene levels, but levels in nonsmokers living in homes with smokers were not increased. ${ }^{69}$ In a second study, increased levels of exhaled benzene were detected in non-smokers living in homes with smokers compared to non-smokers living with non-smokers. ${ }^{68}$ There was no difference in exhaled benzene among children living in homes with smokers or non-smokers. ${ }^{66}$ Collectively, the biomarker data discussed here indicate that benzene uptake in humans is not consistently associated with SHS exposure.

Haemoglobin adducts of ethylene oxide can be quantified by GC-MS of terminal $N$-hydroxyethylvaline. There was no difference in levels of these adducts between non-smokers who did not live or work with a smoker compared to those who did. $^{70}$

Several other less specific markers have been explored in studies of SHS exposure. 8-Hydroxydeoxyguanosine (8-OH$\mathrm{dG}$ ) is a widely used biomarker of oxidative damage to DNA. In two studies, no increase in 8-OH-dG levels in placenta and leucocytes of individuals exposed to SHS was observed..$^{71}$ However, in a study of occupational exposure in Reno, Nevada, the average 8-OH-dG level in whole blood DNA of SHS exposed workers was $63 \%$ higher than that in nonexposed individuals, a significant difference. ${ }^{73}$ Levels of nitrated proteins in blood plasma of non-smokers exposed to SHS were significantly lower than in unexposed nonsmokers, and there was no effect of SHS on levels of oxidised proteins. ${ }^{74}$ Urinary 3-ethyladenine is a biomarker of ethylating agents. In one study, concentrations of 3-ethyladenine in urine were not increased by exposure to $\mathrm{SHS}^{75}{ }^{32} \mathrm{P}$ Postlabelling is a technique which can estimate levels of hydrophobic DNA adducts. Four investigations did not find effects of SHS exposure on levels of ${ }^{32} \mathrm{P}$-postlabelled DNA. ${ }^{41} 7276$ However, a study conducted in Greece did find a relation between SHS exposure and ${ }^{32} \mathrm{P}$-postlabelled DNA adducts in lymphocytes in a subgroup of the subjects examined. ${ }^{78} \mathrm{~A}$ recent study demonstrated no significant increase in levels of ${ }^{32} \mathrm{P}$-postlabelled adducts in induced sputum of individuals exposed to SHS in a pub compared to preexposure levels. However, one of the DNA adducts found in the SHS exposed individuals may have been derived from BaP. ${ }^{79}$

\section{What this paper adds}

Epidemiologic data support the conclusion that exposure to secondhand tobacco smoke causes lung cancer in nonsmokers. Measurement of carcinogen derived biomarkers can further strengthen this conclusion and can provide insights pertinent to mechanisms of cancer induction and modes of cancer prevention.

A review of the use of carcinogen derived biomarkers to assess uptake and metabolism of tobacco smoke carcinogens in people exposed to secondhand tobacco smoke is presented.

Urinary thioethers are conjugates of carbonyl-containing mutagens. Thioethers were not significantly increased as a result of SHS exposure. ${ }^{41} 80$ 3-Hydroxypropyl mercapturic acid, possibly from acrolein exposure, was identified as a possible SHS related product in urine..$^{41}$ Conflicting results have been obtained in studies of urinary mutagenicity as affected by SHS exposure (reviewed $\mathrm{in}^{41}$ and ${ }^{39}$ ). In general, there seem to be small and sometimes significant effects of SHS exposure on urinary mutagenicity when diet is controlled. ${ }^{80}{ }^{81}$ In a study of 1249 Italian women, there was an inverse dose-response relation between intensity of current husband's smoke and concentrations of plasma $\beta$ carotene and L-ascorbic acid. There was a significant inverse association between urinary cotinine and plasma $\beta$ carotene. $^{82}$

\section{SUMMARY}

An overview of the carcinogen derived biomarkers most widely applied in studies of SHS exposure is presented in table 3. Analyses of biomarkers of PAH uptake and metabolic activation have produced mainly mixed results, probably because there are significant exposures to these carcinogens through the diet and general environment. Similarly, mixed results have been reported in studies of benzene and aromatic amine uptake in people exposed to SHS. In contrast to these mixed results, studies which measured the tobacco specific nitrosamine metabolites NNAL and NNAL-Gluc in the urine of people exposed to SHS have shown consistently elevated levels of these biomarkers. The assay for urinary NNAL and NNAL-Gluc is highly specific to carcinogen exposure from SHS because NNK, the parent compound of these metabolites, is found only in tobacco products. The contribution of non-tobacco sources to all other biomarkers discussed here confounds their validity in SHS studies, where carcinogen exposure is generally relatively low.

Studies of NNAL and NNAL-Gluc levels in non-smokers exposed to SHS have provided some potentially significant insights on the role of SHS as a lung carcinogen. Prominent among these are the results of studies of non-smoking women who lived with men who smoked. ${ }^{6}$ The risk for lung cancer in these women is about $20 \%$ greater than in nonexposed non-smoking women. The risk for lung cancer in smokers is $15-20$ times (1500-2000\%) greater than in nonsmokers. ${ }^{83}$ Therefore, the risk for lung cancer in these nonsmoking women exposed to SHS is about $1-2 \%$ as great as that of smokers. ${ }^{63}$ The level of NNAL plus NNAL-Gluc in the urine of the SHS exposed women was about $5.6 \%$ as great as that of their smoking partners, consistent with their comparative $1-2 \%$ risk for lung cancer compared to smokers. ${ }^{55}$ Other studies show a mean of about $0.05 \mathrm{pmol} / \mathrm{ml}$ NNAL plus NNAL-Gluc in non-smokers exposed to SHS. This is about $1.6 \%$ of the typical levels found in smokers, which is also consistent with the results just discussed. These 
carcinogen uptake data provide biochemical support for the role of SHS as a lung carcinogen in non-smokers. The results are particularly relevant because of the established carcinogenicity of NNK to the lungs of rodents, where adenocarcinoma are commonly observed in treated animals, consistent with observations in SHS exposed women.

\section{ACKNOWLEDGEMENTS}

Research in the author's laboratory on tobacco and cancer is supported by grants CA-81301, CA-85702, CA-92025, ES-11297, and DA-13333 from the National Institutes of Health, grant RP-00138 from the American Cancer Society, and a grant from the Flight Attendant Medical Research Institute. I thank members of our laboratory, in particular Steven G Carmella, for their contributions to our research on carcinogen derived biomarkers of SHS exposure.

\section{REFERENCES}

1 International Agency for Research on Cancer. Tobacco smoke and involuntary smoking. IARC Monographs on the Evaluation of Carcinogenic Risks to Humans vol. 83. Lyon, France: IARC, 2003.

2 National Research Council. Environmental tobacco smoke: measuring exposures and assessing health effects. Washington DC: National Academy Press, 1986

3 US Department of Health and Human Services, Public Health Service, National Toxicology Program. Report on carcinogens, 10th ed. Research Triangle Park, North Carolina, 2002.

4 US Department of Health and Human Services. The health consequences of involuntary smoking. A report of the Surgeon General, 1986. Rockville, Maryland: Public Health Service, Centers for Disease Control, 1986; (DHHS Publication No (CDC) 87-8398).

5 Environmental Protection Agency. Respiratory health effects of passive smoking: lung cancer and other disorders, Report No. EPA/600/6-90/ 006F. Washington DC: Office of Health and Environmental Assessment, Office of Research and Development, 1992

6 National Cancer Institute. Health effects of exposure to environmental tobacco smoke: the report of the California Environmental Protection Agency. Smoking and Tobacco Control Monograph No. 10. Bethesda, Maryland: U.S. Dept of Health and Human Services, National Institutes of Health, National Cancer Institute, Dept of Health and Human Services, National Institutes of Health, National Cancer Institute (NIH Publication No. 99-4645, 1999).

7 Jenkins RA, Guerin MR, Tomkins BA. The chemistry of environmental tobacco smoke: composition and measurement, 2nd ed. Boca Raton, Florida: Lewis Publishers, 2000: 1-75.

8 Hecht SS. Tobacco smoke carcinogens and lung cancer. J Natl Cancer Inst 1999:91:1194-210.

9 Swauger JE, Steichen TJ, Murphy PA, et al. An analysis of the mainstream smoke chemistry of samples of the U.S. cigarette market acquired between 1995 and 2000. Regul Toxicol Pharmacol 2002;35:142-56.

10 Hoffmann D, Hoffmann I, El Bayoumy K. The less harmful cigarette: a controversial issue. A tribute to Ernst L. Wynder. Chem Res Toxicol 2001; 14:767-90.

11 International Agency for Research on Cancer. Polynuclear aromatic compounds, part 1. Chemical, environmental, and experimental data. IARC Monographs on the Evaluation of the Carcinogenic Risk of Chemicals to Humans vol. 32. Lyon, France: IARC, 1983:62-6.

12 International Agency for Research on Cancer. Polynuclear aromatic compounds, part 3 . Industrial exposures in aluminum production, coal gasification, coke production, and iron and steel founding. IARC Monographs on the Evaluation of the Carcinogenic Risk of Chemicals to Humans vol. 34. Lyon, France: IARC, 1984:65-131.

13 Thyssen J, Althoff J, Kimmerle G, et al. Inhalation studies with benzo[a]pyrene in Syrian golden hamsters. J Natl Cancer Inst $1981 ; 66: 575-7$

14 Deutsch-Wenzel R, Brune H, Grimmer G. Experimental studies in rat lungs on the carcinogenicity and dose-response relationships of eight frequently occurring environmental polycyclic aromatic hydrocarbons. J Natl Cancer Inst 1983;71:539-44.

15 Brune H, Deutsch-Wenzel RP, Habs $M$, et al. Investigation of the tumorigenic response to benzo(a)pyrene in aqueous caffeine solution applied orally to Sprague-Dawley rats. J Cancer Res Clin Oncol 1981;102:153-7.

16 International Agency for Research on Cancer. Certain polycyclic aromatic hydrocarbons and heterocyclic compounds. IARC Monographs on the Evaluation of the Carcinogenic Risks of Chemicals to Man vol. 3. Lyon, France: IARC, 1972:45-268.

17 International Agency for Research on Cancer. Polynuclear aromatic compounds, part 1. Chemical, environmental, and experimental data. IARC Monographs on the Evaluation of the Carcinogenic Risk of Chemicals to Humans vol. 32. Lyon, France: IARC, 1983:33-91.

18 Culp SJ, Gaylor DW, Sheldon WG, et al. A comparison of the tumors induced by coal tar and benzo[a]pyrene in a two-year bioassay. Carcinogenesis 1998;19:117-24.

19 Preussmann R, Stewart BW. N-Nitroso Carcinogens. In: Searle CE, ed. Chemical carcinogens, second edition, ACS Monograph 182 vol. 2. Washington DC: American Chemical Society, 1984:643-828.
20 Bartsch H, Spiegelhalder B. Environmental exposure to $N$-nitroso compounds (NNOC) and precursors: an overview. Eur J Cancer Prev 1996;5:11-18.

21 Hoffmann D, Hecht SS. Advances in tobacco carcinogenesis. In: Cooper CS, Grover PL, eds. Handbook of experimental pharmacology. Heidelberg: Springer-Verlag, 1990:63-102.

22 Hecht SS, Hoffmann D. Tobacco-specific nitrosamines, an important group of carcinogens in tobacco and tobacco smoke. Carcinogenesis 1988;9:875-84.

23 Hecht SS. Biochemistry, biology, and carcinogenicity of tobacco-specific $\mathrm{N}$-nitrosamines. Chem Res Toxicol 1998;11:559-603.

24 International Agency for Research on Cancer. Some inorganic substances, chlorinated hydrocarbons, aromatic amines, $\mathrm{N}$-nitroso compounds, and natural products. IARC Monographs on the Evaluation of the Carcinogenic Risk of Chemicals to Man vol. 1 Lyon, France: IARC, 1972.

25 International Agency for Research on Cancer. Some aromatic amines, hydrazine and related substances, $\mathrm{N}$-nitroso compounds and miscellaneous alkylating agents. IARC Monographs on the Carcinogenic Risk of Chemicals to Man vol. 4. Lyon, France: IARC, 1973:127-36.

26 Garner RC, Martin CN, Clayson DB. Carcinogenic aromatic amines and related compounds. In: Searle CE, ed. Chemical carcinogens, Second Edition, ACS Monograph 182 vol. 1. Washington DC: American Chemical Society, 1984:175-276.

27 Kerns WD, Pavkov KL, Donofrio DJ, et al. Carcinogenicity of formaldehyde in rats and mice after long-term inhalation exposure. Cancer Res 1983;43:4382-92.

28 International Agency for Research on Cancer. Re-evaluation of some organic chemicals, hydrazine and hydrogen peroxide (part two). IARC Monographs on the Evaluation of the Carcinogenic Risk of Chemicals to Humans vol. 71. Lyon, France: IARC, 1999:319-35.

29 International Agency for Research on Cancer. 1,3-Butadiene. Occupationa exposures to mists and vapours from strong inorganic acids; and other industrial chemicals. IARC Monographs on the Evaluation of Carcinogenic Risks to Humans vol. 54. Lyon, France: IARC, 1992:237-85.

30 International Agency for Research on Cancer. Some industrial chemicals and dyestuffs. IARC Monographs on the Evaluation of the Carcinogenic Risk of Chemicals to Humans vol. 29. Lyon, France: IARC, 1982:93-148.

31 International Agency for Research on Cancer. Re-evaluation of some organic chemicals, hydrazine and hydrogen peroxide (part one). IARC Monographs on the Evaluation of Carcinogenic Risks to Humans vol. 71. Lyon, France: IARC, 1999:109-225.

32 International Agency for Research on Cancer. Beryllium, cadmium, mercury, and exposures in the glass manufacturing industry. IARC Monographs on the Evaluation of Carcinogenic Risks to Humans vol. 58. Lyon, France: IARC, 1999:119-237.

33 International Agency for Research on Cancer. Chromium, nickel, and welding. IARC Monographs on the Evaluation of Carcinogenic Risks to Humans vol. 49. Lyon, France: IARC, 1990:49-445.

34 Pryor WA, Prier DG, Church DF. Electron-spin resonance study of mainstream and sidestream cigarette smoke: nature of the free radicals in gas-phase smoke and in cigarette tar. Environ Health Perspect 1983;47:345-55

35 Pryor WA, Stone K, Zang LY, et al. Fractionation of aqueous cigarette tar extracts: fractions that contain the tar radical cause DNA damage. Chem Res Toxicol 1998;11:441-8.

36 Hanahan D, Weinberg RA. The hallmarks of cancer. Cell 2000;100:57-70.

37 Institute of Medicine. Exposure and biomarker assesment in humans. In: Stratton K, Shetty P, Wallace R, Bondurant S, eds. Clearing the smoke: assessing the science base for tobacco harm reduction. Washington DC: National Academy Press, 2001:309-66.

38 Lee PN. Uses and abuses of cotinine as a marker of tobacco smoke exposure. In: Gorrod JW, Jacob P, III, eds. Analytical determination of nicotine and related compounds and their metabolites. Amsterdam: Elsevier, 1999:669-719.

39 Scherer G, Richter E. Biomonitoring exposure to environmental tobacco smoke (ETS): a critical reappraisal. Hum Exp Toxicol 1997; 16:449-59.

40 Scherer G, Frank S, Riedel K, et al. Biomonitoring of exposure to polycyclic aromatic hydrocarbons of nonoccupationally exposed persons. Cancer Epidemiol Biomarkers Prev 2000;9:373-80.

41 Scherer G, Conze C, Tricker AR, et al. Uptake of tobacco smoke constituents on exposure to environmental tobacco smoke (ETS). Clin Invest 1992;70:352-67

42 Siwinska E, Mielzynska D, Bubak A, et al. The effect of coal stoves and environmental tobacco smoke on the level of urinary 1-hydroxypyrene. Mutat Res 1999;445: 147-53

43 Van Rooij JG, Veeger MM, Bodelier-Bade MM, et al. Smoking and dietary intake of polycyclic aromatic hydrocarbons as sources of interindividual variability in the baseline excretion of 1- hydroxypyrene in urine. Int Arch Occup Environ Health 1994;66:55-65.

44 Hoepfner I, Dettbarn G, Scherer G, et al. Hydroxy-phenanthrenes in the urine of nonsmokers and smokers. Toxicol Lett 1987;35:67-71.

45 Crawford FG, Mayer J, Santella RM, et al. Biomarkers of environmental tobacco smoke in preschool children and their mothers. J Natl Cancer Inst 1994;86:1398-402.

46 Tang D, Warburton D, Tannenbaum SR, et al. Molecular and genetic damage from environmental tobacco smoke in young children. Cancer Epidemiol Biomarkers Prev 1999;8:427-31.

47 Nielsen PS, Okkels H, Sigsgaard T, et al. Exposure to urban and rural air pollution: DNA and protein adducts and effect of glutathione-S-transferase genotype on adduct levels. Int Arch Occup Environ Health 1996;68:170-6.

48 Autrup H, Beck Vestergaard A, Okkels H. Transplacental transfer of environmental genotoxins: polycyclic aromatic hydrocarbon-albumin in 
non-smoking women, and the effect of maternal GSTM1 genotype. Carcinogenesis 1995;16:1305-9

49 Carmella SG, Kagan SS, Kagan M, et al. Mass spectrometric analysis of tobacco-specific nitrosamine hemoglobin adducts in snuff dippers, smokers, and non-smokers. Cancer Res 1990;50:5438-45.

50 Hecht SS, Carmella SG, Murphy SE. Tobacco-specific nitrosamine hemoglobin adducts. Methods Enzymol 1994;231:657-67.

51 Branner B, Kutzer C, Zwickenpflug W, et al. Haemoglobin adducts from aromatic amines and tobacco-specific nitrosamines in pregnant smoking and non-smoking women. Biomarkers 1998;3:35-47.

52 Hecht SS, Carmella SG, Murphy SE, et al. A tobacco-specific lung carcinogen in the urine of men exposed to cigarette smoke. N Engl J Med 1993;329:1543-6.

53 Hecht SS, Ye M, Carmella SG, et al. Metabolites of a tobacco-specific lung carcinogen in the urine of elementary school-aged children. Cancer Epidemiol Biomarkers Prev 2001;10:1109-16.

54 Parsons WD, Carmella SG, Akerkar S, et al. A metabolite of the tobaccospecific lung carcinogen 4-(methylnitrosamino)-1-(3-pyridyl)-1-butanone (NNK) in the urine of hospital workers exposed to environmental tobacco smoke. Cancer Epidemiol Biomarkers Prev 1998;7:257-60.

55 Anderson KE, Carmella SG, Ye M, et al. Metabolites of a tobacco-specific lung carcinogen in the urine of nonsmoking women exposed to environmental tobacco smoke in their homes. J Natl Cancer Inst 2001;93:378-81.

56 Meger M, Meger-Kossien I, Riedel K, et al. Biomonitoring of environmental tobacco smoke (ETS)-related exposure to 4-(methylnitrosamino)-1-(3pyridyl)-1-butanone (NNK). Biomarkers 2000:5:33-45.

57 Hammond SK, Gochlin J, Gann PH, et al. Relationship between environmental tobacco smoke exposure and carcinogen hemoglobin adduct levels in nonsmokers. J Natl Cancer Inst 1993;85:474-8

58 Maclure M, Katz RBA, Bryant MS, et al. Elevated blood levels of carcinogens in passive smokers. Am J Public Heal 1989:79:1381-4.

59 Bartsch H, Caporaso N, Coda M, et al. Carcinogen hemoglobin adducts, urinary mutagenicity, and metabolic phenotype in active and passive cigarette smokers. J Natl Cancer Inst 1990;82:1826-31.

60 Richter E, Rosler S, Scherer G, et al. Haemoglobin adducts from aromatic amines in children in relation to area of residence and exposure to environmental tobacco smoke. Int Arch Occup Environ Health 2001;74:421-8.

61 Grimmer G, Dettbarn G, Seidel A, et al. Detection of carcinogenic aromatic amines in the urine of non-smokers. Sci Total Environ 2000;247:81-90.

62 Scherer G, Renner T, Meger M. Analysis and evaluation of trans, transmuconic acid as a biomarker for benzene exposure. J Chromatogr B Biomed Sci Appl 1998;717:179-99.

63 Yu R, Weisel CP. Measurement of the urinary benzene metabolite trans, trans-muconic acid from benzene exposure in humans. J Toxicol Environ Health 1996;48:453-77.

64 Weaver VM, Davoli CT, Heller PJ, et al. Benzene exposure, assessed by urinary trans, trans-muconic acid, in urban children with elevated blood lead levels. Environ Health Perspect 1996;104:318-23.

65 Carrer $\mathrm{P}$, Maroni M, Alcini D, et al. Assessment through environmental and biological measurements of total daily exposure to volatile organic compounds of office workers in Milan, Italy. Indoor Air 2000;10:258-68.

66 Scherer G, Meger-Kossien I, Riedel K, et al. Assessment of the exposure of children to environmental tobacco smoke (ETS) by different methods. Hum Exp Toxicol 1999;18:297-301.

67 Ruppert T, Scherer G, Tricker AR, et al. trans,trans-muconic acid as a biomarker of non-occupational environmental exposure to benzene. Int Arch Occup Environ Health 1997;69:247-51.

68 Scherer G, Ruppert T, Daube H, et al. Contribution of tobacco smoke to environmental benzene exposure in Germany. Environ Int 1995;21:779-89.

69 Wallace L, Pellizzari E, Hartwell TD, et al. Exposures to benzene and other volatile compounds from active and passive smoking. Arch Environ Health 1987:42:272-9

70 Bono R, Vincenti M, Meineri V, et al. Formation of $\mathrm{N}$-(2-hydroxyethyl)valine due to exposure to ethylene oxide via tobacco smoke: a risk factor for onset of cancer. Environ Res 1999;81:62-71.

71 van Zeeland AA, de Groot AJ, Hall J, et al. 8-Hydroxydeoxyguanosine in DNA from leukocytes of healthy adults: relationship with cigarette smoking, environmental tobacco smoke, alcohol and coffee consumption. Mutat Res 1999;439:249-57.

72 Daube $H$, Scherer G, Riedel K, et al. DNA adducts in human placenta in relation to tobacco smoke exposure and plasma antioxidant status. J Cancer Res Clin Oncol 1997:123:141-51.

73 Howard DJ, Ota RB, Briggs LA, et al. Environmental tobacco smoke in the workplace induces oxidative stress in employees, including increased production of 8-hydroxy-2'-deoxyguanosine. Cancer Epidemiol Biomarkers Prev 1998;7:141-6.

74 Pignatelli B, Li CQ, Boffetta P, et al. Nitrated and oxidized plasma proteins in smokers and lung cancer patients. Cancer Res 2001;61:778-84.

75 Kopplin A, Eberle-Adamkiewicz G, Glüsenkamp KH, et al. Urinary excretion of 3-methyladenine and 3-ethyladenine after controlled exposure to tobacco smoke. Carcinogenesis 1995;16:2637-41.
76 Binkova B, Lewtas J, Miskova I, et al. DNA adducts and personal air monitoring of carcinogenic polycyclic aromatic hydrocarbons in an environmentally exposed population. Carcinogenesis 1995;16:1037-46.

77 Holz O, Krause T, Scherer G, et al. ${ }^{32}$ P-postlabelling analysis of DNA adducts in monocytes of smokers and passive smokers. Int Arch Occup Environ Health 1990;62:299-303.

78 Georgiadis P, Topinka J, Stoikidou M, et al. Biomarkers of genotoxicity of air pollution (the AULIS project): bulky DNA adducts in subjects with moderate to low exposures to airborne polycyclic aromatic hydrocarbons and their relationship to environmental tobacco smoke and other parameters. Carcinogenesis 2001;22:1447-57.

79 Besaratinia A, Maas LM, Brouwer EM, et al. A molecular dosimetry approach to assess human exposure to environmental tobacco smoke in pubs. Carcinogenesis 2002;23:1171-6.

80 Scherer G, Doolittle DJ, Ruppert T, et al. Urinary mutagenicity and thioethers in nonsmokers: role of environmental tobacco smoke (ETS) and diet. Mutat Res 1996:368:195-204.

81 Smith CJ, Bombick DW, Ryan BA, et al. Urinary mutagenicity in nonsmokers following exposure to fresh diluted sidestream cigarette smoke. Mutat Res 2000;470:53-70.

82 Farchi S, Forastiere F, Pistelli R, et al. Exposure to environmental tobacco smoke is associated with lower plasma beta-carotene levels among nonsmoking women married to a smoker. Cancer Epidemiol Biomarkers Prev 2001;10:907-9.

83 Blot W, McLaughlin MK. Passive smoking and lung cancer risk: what is the story now? J Natl Cancer Inst 1998:90:1416-7.

84 Chuang JC, Mack GA, Kuhlman MR, et al. Polycyclic aromatic hydrocarbons and their derivatives in indoor and outdoor air in an eight-home study. Atmos Environ 1991;25B:369-80.

85 Grimmer G Naujack KW Dettbarn G. Gas chromatographic determination of polycyclic aromatic hydrocarbons, aza-arenes, aromatic amines in the particle and vapor phase of mainstream and sidestream smoke of cigarettes. Toxicol Lett 1987;35:117-24

86 Adams JD, O'Mara-Adams KJ, Hoffmann D. Toxic and carcinogenic agents in undiluted mainstream smoke and sidestream smoke of different types of cigarettes. Carcinogenesis 1987;8:729-31.

87 Vu-Duc T, Huynh C-K. Sidestream tobacco smoke constituents in indoor air modelled in an experimental chamber-polycyclic aromatic hydrocarbons. Environ Int 1989:15:57-64.

88 Brunnemann KD, Yu L, Hoffmann D. Assessment of carcinogenic volatile $\mathrm{N}$-nitrosamines in tobacco and in mainstream and sidestream smoke from cigarettes. Cancer Res 1977;37:3218-22.

89 Klus H, Begutter H, Scherer G, et al. Tobacco-specific and volatile $\mathrm{N}$-nitrosamines in environmental tobacco smoke of offices. Indoor Environ 1992;1:348-50.

90 Hoffmann D, Adams JD, Brunnemann KD. A critical look at N-nitrosamines in environmental tobacco smoke. Toxicol Lett 1987:35:1-8.

91 Mahanama KR, Daisey JM. Volatile $\mathrm{N}$-nitrosamines in environmental tobacco smoke: sampling, analysis, emission factors, and indoor air exposures. Environ Sci Technol 1996;30:1477-84.

92 Brunnemann KD, Hoffmann D. Assessment of the carcinogenic $\mathrm{N}$-nitrosodiethanolamine in tobacco products and tobacco smoke. Carcinogenesis 1981;2:1123-7.

93 Brunnemann KD, Masaryk J, Hoffmann D. Role of tobacco stems in the formation of $\mathrm{N}$-nitrosamines in tobacco and cigarette mainstream and sidestream smoke. J Agric Food Chem 1983;31:1221-4.

94 Brunnemann KD, Cox JE, Hoffmann D. Analysis of tobacco-specific $N$-nitrosamines in indoor air. Carcinogenesis 1992;13:2415-8.

95 Patrianakos C, Hoffmann D. Chemical studies in tobacco smoke LXIV. On the analysis of aromatic amines in cigarette smoke. J Anal Toxicol 1979:3:150-4.

96 Government of British Columbia Ministry of Health. What is in cigarettes? Province of British Columbia, 2001. http://www.healthplanning.gov.bc.ca/ $\mathrm{Htdr} /$ index.html.

97 Martin P, Heavner DL, Nelson PR, et al. Environmental tobacco smoke (ETS); a market cigarette study. Environ Int 1997; 23:75-90.

98 Sakuma H, Kusama M, Munakata S, et al. The distribution of cigarette smoke components between mainstream and sidestream smoke. I. Acidic components. Beitr Tabakforsch Int 1983;12:63-71.

$99 \mathrm{Kim} \mathrm{YM}$, Harrad S, Harrison RM. Concentrations and sources of VOCs in urban domestic and public microenvironments. Environ Sci Technol 2001;35:997-1004.

100 Heavner DL, Morgan WT, Ogden MW. Determination of volatile organic compounds and respirable suspended particulate matter in New Jersey and Pennsylvania homes and workplaces. Environ Int 1996;22:159-83.

101 Liu YY, Schmeltz I, Hoffmann D. Chemical studies on tobacco smoke. Anal Chem 1974:46:885-9.

102 Wu D, Landsberger S, Larson WM. Evaluation of elemental cadmium as a marker for environmental tobacco smoke. Environ Sci Technol 1995;29:2311-6.

103 Ferri ES, Baratta EJ. Polonium 210 in tobacco, cigarette smoke, and selected human organs. Public Health Rep 1966;81:121-7. 